\title{
Dengue infection in the nervous system: lessons learned for Zika and Chikungunya
}

\author{
Infecção por dengue no sistema nervoso: lições para Zika e Chikungunya \\ Marzia Puccioni-Sohler1,2, Natalia Roveroni', Carolina Rosadas², Fernando Ferry', Jose Mauro Peralta ${ }^{3}$, \\ Amilcar Tanuri ${ }^{4}$
}

\begin{abstract}
Dengue, Zika and Chikungunya are emerging arboviruses and important causes of acute febrile disease in tropical areas. Although dengue does not represent a new condition, a geographic expansion over time has occurred with the appearance of severe neurological complications. Neglect has allowed the propagation of the vector (Aedes spp), which is also responsible for the transmission of other infections such as Zika and Chikungunya throughout the world. The increased number of infected individuals has contributed to the rise of neurological manifestations including encephalitis, myelitis, meningitis, Guillain-Barré syndrome and congenital malformations such as microcephaly. In this narrative review, we characterize the impact of the geographic expansion of the vector on the appearance of neurological complications, and highlight the lack of highly accurate laboratory tests for nervous system infections. This represents a challenge for public health in the world, considering the high number of travelers and people living in endemic areas.
\end{abstract}

Keywords: Zika virus infection; Dengue; Chikungunya fever; Neurology.

\section{RESUMO}

Dengue, Zika e Chikungunya são arbovírus emergentes e importante causa de doença febril aguda em áreas tropicais. Embora a dengue não represente uma doença nova, houve uma expansão geográfica ao longo do tempo, com o aparecimento de complicações neurológicas graves. A negligência desta situação permitiu a propagação do vetor (Aedes spp) em todo o mundo, que também é responsável pela transmissão de outras infecções pelos vírus Zika e Chikungunya. O grande número de casos infectados contribui para o aumento de manifestações neurológicas incluindo encefalite, mielite, meningite, síndrome de Guillain-Barré e má formações congênitas, como microcefalia. Nesta revisão narrativa, destaca-se o impacto da expansão geográfica do vetor no aparecimento de complicações neurológicas e a falta de testes laboratoriais de elevada acurácia para o diagnóstico da infecção neurológica. Estes aspectos representam desafio para a saúde pública mundial, considerando o grande número de indivíduos que moram ou viajam para áreas endêmicas.

Palavras-chave: infecção pelo Zika virus, Dengue; febre de Chikungunya; Neurologia.

Dengue is one of the most frequent arboviruses (arthropod-borne virus) affecting human beings, and has also been recognized as an important cause of neurological disorders ${ }^{1}$. In recent years, Zika and Chikungunya viruses have emerged as arbovirus agents of neuroinvasive diseases $^{2-4}$. Clinical manifestations present with a similar pattern to that observed in dengue infection, including rash, acute fever, and severe neurological complications. Dengue and Chikungunya may become the main causes of encephalitis over the next decade due the increasing number of infected individuals. All three arboviruses can cause the ascending paralysis of Guillain-Barré syndrome $^{1,3}$. Also, Zika infection has recently been associated with microcephaly ${ }^{5}$.

Dengue epidemics are not a new health public problem in the world ${ }^{1}$. During the eighteenth and nineteenth centuries, the virus spread to tropical and subtropical regions, exposing the four billion people, who currently live in those areas, to the risk of contracting the infection. Fifty to 100 million individuals are diagnosed

\footnotetext{
'Universidade Federal do Estado do Rio de Janeiro (UNIRIO), Escola de Medicina e Cirurgia, Hospital Universitário Gaffree e Guinle, Rio de Janeiro RJ, Brasil; Universidade Federal do Rio de Janeiro (UFRJ), Faculdade de Medicina, Pós-graduação em Doenças Infecciosas e Parasitárias, Rio de Janeiro RJ, Brasil; ${ }^{3}$ Universidade Federal do Rio de Janeiro (UFRJ), Instituto de Microbiologia Professor Paulo de Góes, Rio de Janeiro RJ, Brasil;

«Universidade Federal do Rio de Janeiro (UFRJ), Instituto de Biologia, Rio de Janeiro RJ, Brasil.
}

Correspondence: Marzia Puccioni-Sohler; Universidade Federal do Estado do Rio de Janeiro (UNIRIO), Escola de Medicina e Cirurgia/ Hospital Universitário Gaffree e Guinle; Rua Mariz e Barros 775; 20270-004 Rio de Janeiro RJ, Brasil; E-mail: m_puccioni@yahoo.com.br

Conflict of interest: There is no conflict of interest to declare.

Support: Fundação Carlos Chagas de Amparo a Pesquisa do Estado do Rio de Janeiro (FAPERJ) (E-26/201.330/2016), edital Arbovírus, and PhD scholarship from Coordenação de Aperfeiçoamento de Pessoal de Nivel Superior (CAPES), Brazil for C. R.

Received 22 September 2016; Accepted 10 October 2016. 
annually. Consequently, 20,000 deaths occur per year due to transmission of dengue ${ }^{1}$. Despite the fact that the Zika virus (ZIKV) was isolated in 1947 in Rhesus monkeys in Uganda, it was first identified in humans only five years later, in Nigeria. Occasional cases were reported in other African and Asian countries ${ }^{6}$. During 2007, an outbreak occurred on the island of Yap (Micronesia), where the infection was symptomatic in $18 \%$ of the cases 6 . In Brazil, the first report of autochthonous transmission of ZIKV was confirmed in May 2015, in the state of Bahia. It was then established that genomic characteristics identified in the country were similar to the virus isolated in French Polynesia, during the outbreak of $2013^{5,7}$. From 2013 to February 2016, cases of ZIKV infection have been registered in 28 countries in Latin America and the Caribbean ${ }^{8}$. As for the Chikungunya virus (CHIKV), it was isolated in humans in 1952 in Tanzania. Its name originally comes from Swahili or Makonde, a dialect of Tanzania, meaning "one who walks with the arched back". In 2000, a state of emergency was raised due to the CHIKV fever epidemics both in Africa and Asia, with subsequent spread to the Indian Ocean, Europe and the Caribbean. Chikungunya fever research remained limited until the epidemic on Reunion Island in 2006, during which roughly a third of its population $(\mathrm{n}=266,000)$ was affected by CHIKV, resulting in 203 casualties ${ }^{2,9}$.

The first case of CHIKV infection in Brazil was diagnosed in 2010 in Rio de Janeiro ${ }^{10}$. In 2014, the first reports of indigenous transmission and outbreak in the city of Feira de Santana (Bahia) came out in Brazil ${ }^{11}$.

\section{UNCONTROLLED COMMON VECTOR TRANSMISSION WORLDWIDE}

The mosquito Aedes spp is the main vector for dengue virus (DENV) transmission, as well as for ZIKV and CHIKV ${ }^{11,12}$. Lack of control of vector proliferation is the most important event responsible for the vast and accelerated spread of these emerging viral infections, which can cause subsequent severe neurological complications in hosts who live in previously unaffected regions. Contamination to vertebrates occurs through the bite of infected mosquitos, which procreate and become infected by blood feeding in another viremic host. Nevertheless, new reports have led to the belief that ZIKV transmission may also occur through different mechanisms, including via placenta, sexually, or perinatally ${ }^{5,13}$. Moreover, descriptions of perinatal transmission have been found in individuals infected with $\mathrm{CHIKV}^{2}$. Dengue and Zika viruses belong to the genus Flavivirus, and Chikungunya to the genus Alphavirus ${ }^{1}$. There are five distinct serotypes of DENV (1-5), with DENV 1-4 responsible for causing the disease in humans ${ }^{1}$.

\section{WARNING OF NEUROLOGICAL COMPLICATIONS OF} DENGUE, ZIKA, AND CHIKUNGUNYA

The association between DENV infection and neurological manifestations was first described in $1976^{1}$. The frequency of neurological impairment has been reported in $1-21 \%$ of dengue cases ${ }^{14-16}$. These events, though rare, have been shown to be caused specially by serotypes DENV-2 and DENV-3, which are neurotropic ${ }^{1}$. These viruses were identified in cases of meningitis, myelitis, and encephalitis ${ }^{1,14,17}$. There have also been DENV-1 and DENV-4 identified in biological samples from patients diagnosed with encephalitis and myelitis ${ }^{18}$. Subsequently, DENV antigen has been detected in brain tissue samples of deceased patients. As well, DENV-2, DENV-3, and DENV-4 have been found in the cerebrospinal fluid (CSF), by reverse transcriptase polymerase chain reaction technique ${ }^{1,19}$. Encephalitis and encephalopathy are certainly the most common neurological complications ${ }^{14}$. The mechanism involving the nervous system includes direct pathogen aggression, followed by activation of autoimmune factors, metabolic and bleeding disorders ${ }^{1,17}$. Other neurological complications include: Guillain-Barré syndrome, Miller-Fisher syndrome, acute disseminated encephalomyelitis, optic neuromyelitis, optic neuritis, and myositis $^{1,14,20,21,22,23,24,25}$. In some cases, neurological disease may be the first manifestation of DENV infection ${ }^{17,26}$. Mortality rates range between $5-8 \%$, mostly due to cerebral edema and herniation. Furthermore, sequelae are reported in $20-30 \%$ of the patients, including spastic paraparesis associated with myelitis, mental confusion and personality change in cases of encephalitis ${ }^{1,14}$.

During the ZIKV outbreak in French Polynesia in 2013, neurological complications were identified in 73 patients with Zika fever. Among them, 42 cases (57\%) presented with Guillain-Barré syndrome. Additionally, there were reports of encephalitis, meningoencephalitis, facial paralysis, and acute myelitis associated with ZIKV infection ${ }^{3,5,8}$. In February 2016, the World Health Organization declared ZIKV infection a public health emergency, issuing a global alert about its relationship to cases of microcephaly, considering that the viral genome was found in blood samples and tissues of microcephalic neonates ${ }^{27}$. Moreover, amniotic fluid analysis of microcephalic fetuses from pregnant women found ZIKV infection, inferring transplacental transmission ${ }^{5,28}$. This fact could explain the increased number of microcephaly cases reported in Brazil. Other congenital malformations, such as lissencephaly, ventriculomegaly, cerebellar hypoplasia, cortical atrophy with cerebral calcifications, and arthrogryposis have also been described in cases of ZIKV congenital infection ${ }^{5,29,30}$. With respect to these findings, Garcez et al. indicated that ZIKV may cause impairment in the growth of neural cell population. It has been know since 1960-1970 that CHIKV can affect the 
central nervous system. Myelitis, when present, is usually associated with encephalitis ${ }^{2,31}$. Guillain-Barré syndrome, optic neuritis, facial paralysis, acute disseminated encephalomyelitis, peripheral neuropathy, and myopathy have also been described in CHIKV infection ${ }^{2,32,33,34}$.

\section{LABORATORY DIAGNOSIS}

The definite diagnosis of dengue, Zika, and Chikungunya infection is based on laboratory tests, as symptoms to these diseases are nonspecific. The ZIKV has been found by culture or reverse transcriptase polymerase chain reaction during the first days of infection ${ }^{27,31,35}$. Detection of specific IgM antibodies or increased titer of specific IgG in serum occurs 5-10 days after onset of symptoms and persists for many weeks to three months. However, false-positive serological results may occur due the presence of cross-reacting antibodies against dengue $^{1}$. Diagnosis of neurological manifestations associated with DENV/CHIKV infection are determined by specific IgM antibodies, increasing IgG antibodies titers, viral antigens, RNA fragments in samples of blood/CSF or the intrathecal synthesis of anti-specific antibodies in dengue patients ${ }^{1,17,26,36,37,38}$. Despite the detection of IgM antibodies for Zika virus in the CSF of neonates with microcephaly, there is an immaturity of the blood-brain and blood-CSF barrier in neonates, which increases the permeability to serum proteins ${ }^{39}$. After the acute viremia period, ZIKV can also be detected in the urine within two weeks as well in other fluids. ${ }^{7,40}$

\section{PERSPECTIVES AND FUTURE DIRECTIONS}

Emerging arboviruses cause a group of acute febrile diseases that include dengue, Chikungunya, and Zika. They induce emerging and re-emerging epidemics in developing countries and represent a common cause of illness in travelers worldwide ${ }^{20}$. Importantly, there is still no effective antiviral treatment available, nor vaccines, nor adequate prevention by vector control, education of community, or public health politics. The rising number of infected individuals may increase the cases with severe neurological disorders. Clinical manifestations are similar to other viral infections (herpes simplex virus, cytomegalovirus, varicella zoster virus, and enterovirus), which are also highly prevalent in these endemic areas. Moreover, co-infection with other agents may promote the emergence of complicated cases, such as those presenting with neurological symptoms. There is still a lack of knowledge about the pathophysiological mechanisms of neurological disorders that affect certain patients ${ }^{41}$. Furthermore, absence of reliable laboratory tests aiming at early and accurate diagnosis of infection in the nervous system is significant. Finally, the analysis of clinical characteristics and CSF fluid of patients displaying neurological manifestations related to arboviruses is crucial, in order to determine the development of the disease mechanisms and improve diagnostic methods of infection within each virus group. Such information is of great importance for proper handling and treatment of infected patients.

\section{References}

1. World Health Organization. Dengue: guidelines for diagnosis, treatment, prevention and control. Geneva:World Health Organization; 2009.

2. Burt FJ, Rolph MS, Rulli NE, Mahalingam S, Heise MT. Chikungunya: a re-emerging virus. Lancet. 2012;379(9816):662-71. http://doi.org/10.1016/S0140-6736(11)60281-X

3. Cao-Lormeau VM, Blake A, Mons S, Lastère S, Roche C, Vanhomwegen J et al. Guillain-Barré Syndrome outbreak associated with Zika virus infection in French Polynesia: a case-control study. Lancet. 2016;387(10027):1531-9. http://doi.org/10.1016/S0140-6736(16)00562-6

4. Grange L, Simon-Loriere E, Sakuntabhai A, Gresh L, Paul R, Harris E. Epidemiological risk factors associated with high global frequency of inapparent dengue virus infections. Front Immunol. 2014;5:280. http://doi.org/10.3389/fimmu.2014.00280

5. Calvet G, Aguiar RS, Melo AS, Sampaio SA, Filippis I, Fabri A et al. Detection and sequencing of Zika virus from amniotic fluid of fetuses with microcephaly in Brazil: a case study. Lancet Infect Dis. 201616(6):653-60. http://doi.org/10.1016/S1473-3099(16)00095-5

6. Duffy MR, Chen TH, Hancock WT, Powers AM, Kool JL, Lanciotti RS et al. Zika virus outbreak on Yap Island, Federated States of Micronesia. N Engl J Med. 2009;360(24):2536-43. http://doi.org/10.1056/NEJMoa0805715

7. Zanluca C, Melo VC, Mosimann AL, Santos GI, Santos CN, Luz K. First report of autochthonous transmission of Zika virus in Brazil. Mem Inst Oswaldo Cruz. 2015;110(4):569-72. http://doi.org/10.1590/0074-02760150192
8. Mécharles S, Herrmann C, Poullain P, Tran TH, Deschamps N, Mathon $G$ et al. Acute myelitis due to Zika virus infection. Lancet. 2016; 387(1026):1481. http://doi.org/10.1016/S0140-6736(16)00644-9

9. Lanciotti RS, Lambert AJ. Phylogenetic analysis of Chikungunya Virus strains circulating in the Western hemisphere. Am J Trop Med Hyg. 2016;94(4):800-3. http://doi.org/10.4269/ajtmh.15-0375

10. Albuquerque IG, Marandino R, Mendonça AP, Nogueira RM, Vasconcelos PF, Guerra LR et al. Chikungunya virus infection: report of the first case diagnosed in Rio de Janeiro, Brazil. Rev Soc Bras Med Trop. 2012;45(1):128-9. http://doi.org/10.1590/S0037-86822012000100026

11. Azevedo RSS, Oliveira CS, Vasconcelos PF C. Chikungunya risk for Brazil. Rev Saúde Pública. 2015;49:58. http://doi.org/10.1590/S0034-8910.2015049006219

12. Weaver SC, Lecuit M. Chikungunya virus and the global spread of a mosquito-borne disease. N Engl J Med. 2015;372(13):1231-9. http://doi.org/10.1056/NEJMra1406035

13. Musso D. Zika Virus transmission from French Polynesia to Brazil. Emerg Infect Dis. 2015;21(10):1887. http://doi.org/10.3201/eid2110.151125

14. Carod-Artal FJ, Wichmann O, Farrar J, Gascón J. Neurological complications of dengue virus infection. Lancet Neurol. 2013;12(9):906-19. http://doi.org/10.1016/S1474-4422(13)70150-9

15. Thisyakorn U, Thisyakorn C, Limpitikul W, Nisalak A. Dengue infection with central nervous system manifestations. Southeast Asian J Trop Med Public Health. 1999;30(3):504-6. 
16. Solomon T, Dung NM, Vaughn DW, Kneen R, Thao LT, Raengsakulrach $B$ et al. Neurological manifestations of dengue infection. Lancet. 2000;355(9209):1053-9. http://doi.org/10.1016/S0140-6736(00)02036-5

17. Puccioni-Sohler M, Soares CN, Papaiz-Alvarenga R, Castro MJ, Faria LC, Peralta JM. Neurologic dengue manifestations associated with intrathecal specific immune response. Neurology. 2009;73(17):1413-7. http://doi.org/10.1212/WNL.0b013e3181bd8258

18. Ramos C, Sánchez G, Pando RH, Baquera J, Hernández D, Mota J et al. Dengue virus in the brain of a fatal case of hemorrhagic dengue fever. J Neurovirol. 1998;4(4):465-8. http://doi.org/10.3109/13550289809114548

19. Araújo FMC, Araújo MS, Nogueira RM, Brilhante RS, Oliveira DN, Rocha MF et al. Central nervous system involvement in dengue: a study in fatal cases from a dengue endemic area. Neurology. 2012;78(10):736-42. http://doi.org/10.1212/WNL.0b013e31824b94e9

20. John CC, Carabin H, Montano SM, Bangirana P, Zunt JR, Peterson PK. Global research priorities for infections that affect the nervous system. Nature. 2015;527(7578):S178-86. http://doi.org/10.1038/nature16033

21. Lebrun G, Chadda K, Reboux AH, Martinet O, Gaüzère BA. Guillain-Barré syndrome after chikungunya infection. Emerg Infect Dis. 2009;15(3):495-6. http://doi.org/10.3201/eid1503.071482

22. Miranda de Sousa A, Puccioni-Sohler M, Dias Borges A, Fernandes Adorno L, Papais Alvarenga M, Papais Alvarenga RM. Post-dengue neuromyelitis optica: case report of a Japanese-descendent Brazilian child. J Infect Chemother. 2006;12(6):396-8. http://doi.org/10.1007/s10156-006-0475-6

23. Misra UK, Kalita J, Mani VE, Chauhan PS, Kumar P. Central nervous system and muscle involvement in dengue patients: a study from a tertiary care center.J Clin Virol. 2015;72:146-51. http://doi.org/10.1016/j.jcv.2015.08.021

24. Sousa AM, Alvarenga MP, Alvarenga RM. A cluster of transverse myelitis following dengue virus infection in the brazilian Amazon region. Trop Med Health. 2014;42(3):115-20. http://doi.org/10.2149/tmh.2014-06

25. Yamamoto Y, Takasaki T, Yamada K, Kimura M, Washizaki K, Yoshikawa Ket al. Acute disseminated encephalomyelitis following dengue fever.J Infect Chemother. 2002;8(2):175-7. http://doi.org/10.1007/s101560200030

26. Soares CN, Cabral-Castro MJ, Peralta JM, Freitas MR, Puccioni-Sohler M. Meningitis determined by oligosymptomatic dengue virus type 3 infection: report of a case. Int J Infect Dis. 2010;14(2):e150-2. http://doi.org/10.1016/j.ijid.2009.03.016

27. Gulland A. Zika virus is a global public health emergency, declares WHO. BMJ.; 2016;352:i657. http://doi.org/10.1136/bmj.i657

28. Noronha L, Zanluca C, Azevedo MLV, Luz KG, Santos CND. Zika virus damages the human placental barrier and presents marked fetal neurotropism. Mem Inst Oswaldo Cruz. 2016;111(5):287-93. http://doi.org/10.1590/0074-02760160085
29. Garcez PP, Loiola EC, Costa RM, Higa LM, Trindade P, Delvecchio $R$ et al. Zika virus impairs growth in human neurospheres and brain organoids. Science. 2016;352(6287):816-8. http://doi.org/10.1126/science.aaf6116

30. Oliveira-Szejnfeld PS, Levine D, Melo ASO, Amorim MMR, Batista AGM, Chimelli L et al. Congenital brain abnormalities and Zika Virus: what the radiologist can expect to see prenatally and postnatally. Radiology. 2016;281(1):161584. http://doi.org/10.1148/radiol.2016161584

31. Carteaux G, Maquart M, Bedet A, Contou D, Brugières P, Fourati S et al. Zika Virus associated with meningoencephalitis. N Engl J Med. 2016;374(16):1595-6. http://doi.org/10.1056/NEJMc1602964

32. Robin S, Ramful D, Le Seach'F, Jaffar-Bandjee MC, Rigou G, Alessandri JL. Neurologic manifestations of pediatric chikungunya infection. J Child Neurol. 2008;23(9):1028-35. http://doi.org/10.1177/0883073808314151

33. Wielanek AC, Monredon J De, Amrani M El, Roger JC, Serveaux JP. Guillain-Barré syndrome complicating a Chikungunya virus infection. Neurology. 2007;69(22):2105-7. http://doi.org/10.1212/01.wnl.0000277267.07220.88

34. Puccioni-Sohler M, Salgado MCF, Versiani I, Rosadas C, Ferry F, Tanuri A, Ferreira Jr. OC. Carpal tunnel syndrome after Chikungunya infection. Int J Infect Dis. 2016; 53: 21-22

35. Lanciotti RS, Kosoy OL, Laven JJ, velez JO, lambert AJ, Johnson AJ, Stanfield SM, Duffy MR. 2008. Genetic and serologic properties of Zika virus associated with an epidemic, Yap State, Micronesia, 2007. Emerg Infect Dis. Aug; 14(8):1232-1239

36. Soares CN, Cabral-Castro MJ, Peralta JM, Freitas MRG, Zalis M, Puccioni-Sohler M. Review of the etiologies of viral meningitis and encephalitis in a dengue endemic region. J Neurol Sci. 2011;303(1-2):75-9. http://doi.org/10.1016/j.jns.2011.01.012

37. Soares CN, Faria LC, Peralta JM, Freitas MRG, Puccioni-Sohler M. Dengue infection: neurological manifestations and cerebrospinal fluid (CSF) analysis. J Neurol Sci. 2006;249(1):19-24. http://doi.org/10.1016/j.jns.2006.05.068

38. Kashyap RS, Morey SH, Chandak NH, Purohit HJ, Taori GM, Daginawala HF. Detection of viral antigen, IgM and IgG antibodies in cerebrospinal fluid of Chikungunya patients with neurological complications. Cerebrospinal Fluid Res. 2010;7(1):12. http://doi.org/10.1186/1743-8454-7-12

39. Cordeiro MT, Pena LJ, Brito CA, Gil LH, Marques ET. Positive IgM for Zika virus in the cerebrospinal fluid of 30 neonates with microcephaly in Brazil. Lancet. 2016;387(10030):1811-2. http://doi.org/10.1016/S0140-6736(16)30253-7

40. Rozé B, Najioullah F, Signate A, et al. Zika virus detection in cerebrospinal fluid from two patients with encephalopathy, Martinique, February 2016. Eurosurveillance. 2016;21(16):2. http://doi.org/10.2807/1560-7917.ES.2016.21.16.30205

41. Puccioni-Sohler M, Rosadas C. Advances and new insights in the neuropathogenesis of dengue infection. Arq Neuropsiquiatr. 2015;73(8): 698-703. http://doi.org/10.1590/0004-282X20150074 